\title{
SMALL TOWNS AS MEDIATORS TOWARDS SPATIAL RESILIENCE: THE CASE STUDY OF NETWORK OF SETTLEMENTS IN VOJVODINA REGION
}

UDC 711.435(497.113)

\author{
Ivan Simić ${ }^{1}$, Ratko Bajčetić ${ }^{2}$ \\ ${ }^{1}$ University of Belgrade, Faculty of Architecture, Belgrade, Serbia \\ ${ }^{2}$ University of Novi Sad, Faculty of Technical Sciences, Novi Sad, Serbia
}

\begin{abstract}
The development of settlements in Vojvodina is burdened by numerous problems, both environmental and social, which seriously jeopardize their path towards resilience. The effects of climate changes have been identified mostly in the form of floods, inundations and prolonged droughts affecting agriculture as the dominant activity in the region. On the other hand, settlements in Vojvodina, especially small towns and villages, suffer from chronic depopulation and the 'emptying' effect. Naturally, this transfers its consequences to major cities and the entire regional network of settlements.

In this article we will focus on a particular type of settlement in Vojvodina - small towns, specific because of their urban-rural character and their significance within the above-mentioned issues. What are the possibilities for this type of settlement to improve its ecological resilience, a property that is the conditio sine qua non of sustainability? Our assumption is that small towns, due to their hybrid urban-rural character, possess sufficient flexibility and polyvalence to take on the role of the 'fluid object' i.e. the mediator that allows the proliferation of relational objects between urban and rural areas, and that will allow spatial resilience of the entire network of settlements. We will use the concept of spatial resilience in order to extend the question of ecological resilience of one type of settlement to the entire network of towns.
\end{abstract}

Key words: spatial resilience, social-ecological systems, small towns, network of settlements in Vojvodina, spatial and urban planning.

Received March 25, 2016 / Accepted May 9, 2016

Corresponding author: Ivan Simić

University of Belgrade, Faculty of Architecture, Bulevar Kralja Aleksandra br. 73/II, 11000 Belgrade, Serbia

E-mail: ivan.simic@arh.bg.ac.rs 


\section{Human SETTLEMENTS AS SOCIAL-ECOLOGICAL SYSTEMS}

Cities are urban ecosystems that, unlike natural ecosystems, create large ecological footprint that reflects in degradation of natural habitats, as well as in the loss of biodiversity and ecosystem services (Alberti 1999). The consequences brought along with urbanization processes are vital for the functioning of the ecosystem and its basic features. The main adverse effects on the environment are being shown through pollution of waterways, loss of biodiversity and climate change (ibid.).

Capacity of the environment, from local ecosystems to the biosphere, to sustain societal development seems to have been reduced over historical time and at increasing pace during the past century. At the same time, the capacity of ecosystems to remain within desired states in the face of abrupt change seems to have been reduced as a consequence of human actions. (Folke et al. 2005).

In this paper, we address the question of sustainable development of small towns in Vojvodina region using the latest findings from the theory of resilient systems. In order to give an adequate answer, we establish an interdisciplinary research framework, which integrates urban and spatial planning with a discourse of urban ecology. Contemporary approach of urban ecology termed "ecology of the city" (as opposed to "ecology in the city") takes a multidisciplinary stance to understand the integrated social-ecological system by synthesizing the ecological understanding of specific organisms and processes, social behaviours, and the feedbacks among them (Cadenasso and Pickett 2013).

Understanding cities as static systems with one optimal stable state moved forward towards the knowledge that they are in fact dynamic, open systems, subject to constant changes with more stable states. This completely changed the understanding of sustainability. Today, reaching sustainability is considered to be a constant process of adaptation and response to new conditions and sudden impacts.

How did this sustainability paradigm shift affect the development of spatial and urban planning? New understanding of sustainability brings up the question of uncertainty and unpredictability of the future state of the system, i.e. the possibilities of urban planning and design to predetermine and fully anticipate the development of a human settlements. In this paper we will deal with sustainable development of small towns in Vojvodina from the aspect of a recent theory of ecological resilience which brings about sustainability paradigm shift and value basis of spatial and urban planning.

We will consider small towns to be systems containing both social and ecological component. We will use the term 'social-ecological' system coined by Berkes \& Folke (1998) to emphasize the integrated concept of humans in nature and stress that delineation between social and ecological systems is artificial and arbitrary. Research suggests that social-ecological systems have powerful reciprocal feedbacks and act as complex adaptive systems (CAS); hence, cities may be seen as quintessential examples of CAS. Such systems are characterized by self-organization, in which local interactions on a smaller scale result in the formation of patterns on a larger scale. In addition, they are also characterized by adaptive processes, i.e. processes of constant transformation in conditions of uncertainty and surprise. Based on these findings on CAS, the theory of ecological resilience has been developed.

From the perspective of resilience, sustainability does not mean keeping the system in a state of equilibrium by reducing the variability in the dynamics of the system, or optimizing system performances, but rather sustainability needs to be oriented towards 
the capacity of the system to create and test conditions and preservation of adaptive capacity (Holling 2001). Therefore, resilience is the key to sustainability in socialecological systems (Walker and Salt 2006). Preservation of the ability to self-organize faced with disorders is the crucial feature of resilient systems. According to $\mathrm{Wu}$ and $\mathrm{Wu}$ (2013), all sustainable systems must be resilient, but not necessarily stable.

Based on the observation that ecosystems often have multiple alternate states Holling (1973) defined resilience as the ability of a system to absorb change and disturbance without changing its basic structure and function or shifting into a qualitatively different state. The resilience concept based on multiple alternate states has been called "ecological resilience" or "ecosystem resilience," which stresses persistence, change, and unpredictability (Holling 1996). The ecological approach to resilience involves and affirms the fact that world is in constant flux, and does not take an interest in the ability to return to a kind of original state. Instead, it takes an interest in the possibility of adapting to external or internal processes not by keeping still, but rather by „staying 'in the game'“ (Pickett, Cadenasso and Grove 2004).

\section{From ECOLOGICAL TOWARDS SPATIAL RESILIENCE}

Seen from a purely ecological point of view of the environment, it can be said that there are several groups of theories which can be broadly categorized into three basic groups:

1. EGOcentric, also known as Anthropological group of theories, which is based on the postulates of the central role of man and the subordination of the entire ecosystem to him. According to these theories, man is a "supreme being," and all activities in the eco-system adjust to his interests and his "well-being";

2. ECOcentric group of theories, which is based on man being an equally important part of the ecosystem in relation to its other parts. This group of theories regards causality of activities of each of the factors of the ecosystem, with special attention to human activity that may, or may not have impact on any part of the ecosystem. The overall postulate of this group of theories is based on the conclusion made by Karl August Möbius (Allaby 2009), that all living beings of a system must be seen only as a part of the whole community that exists in the same habitat and they cannot exist independently of other beings in the community.

3. Resource group, also known as economic group of theories, which is based on preservation, especially of renewable resources. It is close to ECOcentric group of theories, but it emphasizes the future needs of humanity in relation to all the other factors of the ecosystem. According to some authors, this group of theories is a part of ECOcentric group of theories.

ECOcentric theoretical assumptions served as the basis for the creation of the concept of the so-called ECOcentric management whose aim is to improve the resilience of the ecosystem factors, regardless of the fact that there are no potential direct economic benefits. Thus, preference is given to social-ecological benefits of the whole system, that is, to the creation of a new, better level of life and environment.

However, how shall resilience be formulated in the case of the area that extends beyond the individual ecosystem, i.e. individually observed settlement? We can assume that if we want to define resilience of an urban ecosystem, for example, a small town in 
Vojvodina, it is necessary to view it in a broader inclusive spatial context, without clearly drawn boundaries, with established relations of interdependence on other wider socialecological systems.

The idea of spatial resilience first appeared in the ecology of coral reefs, where Nyström and Folke took also into account the processes that extend beyond the scope of an individual ecosystem: „Spatial resilience is the dynamic capacity to cope with disturbance and thresholds on spatial scales larger than individual ecosystems." (Nyström and Folke 2001). It is a concept that ecosystem puts into the context of spatial integration, circulation and interdependence through multiple spatial levels, on wider systems it belongs to, but also on the more narrow systems that comprise it.

In order to form an integral frame for the qualification of spatial resilience of urban ecosystems, i.e. small towns in Vojvodina, will use the concepts of three disciplinary discourses: (1) the ecological discourse and concepts of panarchy and metacity, (2) the philosophical discourse and concepts of environment ('milieu') and network of towns and (3) the architectural discourse and concepts of polyvalence and flexibility.

(1) Ecological concepts annul the division into urban/rural and nature, emphasizing connectivity and continuity of movement from one area to another. Pickett and Cadenasso (2013) describe these conditions as spatial and organizational complexity, dynamism, and hybridity that seem to call for a new conception of urban systems. First, they introduced multi-faceted term to stand for the spatial extent and inclusivenes of urban systems: the CitySuburban-Exurban system (CSE). This spatial integration is the first step in conceptualizing the metacity as a tool for resilient, ecological urban design. Second, they introduced a concept of Metacity, by using prefix 'meta' to depict a system of systems. The use of meta prefix places the metacity in a nested hierarchical framework.

The term metacity can be used to refer to a single city as a system of spatially differentiated and differentially connected mosaics. These mosaics, like the metapopulations and metacommunities of ecological science, are thus systems of systems. Hence, a coarser scale spatial model of nested, functional mosaics with their internal and external connections emerges from placing the metacity in its larger context. Ecological scientists refer to such nesting of systems as a panarchy ${ }^{1}$. Emphasis is on the need to understand a system of interest based on the finer scale systems it contains as well as the systems in which it is embedded. Both the embedded and containing systems are spatial and dynamic. 'Meta' as used in ecology highlights both the nesting and the dynamism of urban systems.

According to Deleuze and Guattari (1980) a town does not exist as a single object, but always as a function of circulation, a remarkable point on the circuits that create it, and which it creates. A town is always in relation to other towns that make up the network but at the same time the network makes them: It is a phenomenon of transconsistency, a network, because it is fundamentally in contact with other towns.

Deleuze and Guattari place a city in the context of sort of nested systems: "this town, which is always part of a network, constitutes a power of the milieu, a power of the environment, the Umwelt. If I am in the town, then it is my environment, but the town itself is between other towns, which make its environment. Any 'thing' can be described as an environment if we think of it at an appropriate scale."

The power of milieu and panarchy are the concepts that match as they both represent the horizontally established interdependence between nodes, the forced coordination. Towns are circuit points of every kind, which enter into counterpoint along horizontal 
lines; they affect complete but local, town by town, integration. Each one constitutes a central power, but it is a power of polarisation or of the environment (milieu), of forced coordination (Deleuze and Guattari 1980). Due to this inherent relationship between the town and its 'milieu', it is necessary to expand the context of ecological resilience of a town as an urban ecosystem.

(3) Karrholm (2012) introduces the concept of spatial resilience transferring it to the discourse of urban planning and architecture. He performs analysis of the discourse of ecology, architecture and philosophy and links it first to the concepts of spatial flexibility (architects structuralists of the 50s) and polyvalence, as well as upgrade of flexibility: From a spatial point of view, concept of resilient spaces or a resilient city bears resemblances to the architectural concept of flexibility. As a concept, flexibility was often used to denote the possibility of changing the built structure in different ways and was later updated by Hertzberger as related concept of polyvalence (Hertzberger 2001). Karrholm finds this Hertzberger's definition of polyvalence very much related to the concept of resilience and based on it provides a definition of spatial resilience from the perspective of urban planning and architecture: Spatial resilience is ability of spaces to cope with diversity and change while retaining their identity. Spatial resilience indicates the possibility of different usages, adaptations, affordances and even changes without changing identity altogether and becoming something other than itself. Regardless of the discipline and research discourse, it always involves circulation, dynamism and fluidity, as well as the relations of interdependence and existence (of urban system), which it assumes only within such a network. In short, spatial resilience comprises a network of flows of matter, inert or living, things or people.

In ecology megaregions comprise metacities, and change in such regions are themselves a metadynamic driven by changes within and between their metacities, as well as changes and connections in the larger global network of economy, resource flow, flows of genetic information, of biota, and of people. Virtual and literal connections are both important in the metacities and their larger context (Pickett et al. 2013).

Deleuze and Guattari (1980) presuppose existence of the city "only as a function of circulation, and of circuits; it is a remarkable point on the circuits that create it, and which it creates. It is defined by entries and exits; something must enter it and exit from it. It imposes a frequency. It affects a polarization of matter, inert, living or human; it causes the phylum, the flow, to pass through specific places, along horizontal lines." Towns, environments and subjects are presented as correlates of relation, the product of networks and flows.

Karrholm also claims that "polyvalent or resilient spaces can be described in terms of fluidity or, to be more specific, fluid topology. Fluid objects constitute a fluid stabilisation network through proliferation of objects of relation that act as mediators between the two spaces. In topological sense, fluid objects consist of a set of actors that all share a certain family resemblance. By acknowledging fluidity as a kind of spatial stabilisation, one might also open up for strategies that connect to new actors, previously 'other' than original ones.

Relying on the aforementioned concepts, we will define the conditions for reaching spatial resilience of settlements as social-ecological systems. Firstly, it is impossible without a broader framework, their immanent milieu, i.e. a network of metaregions, metacities and metasettlements constituted by the structure of panarchy and information flows, animate and inanimate world. Secondly, in this constellation of settlements, each individual settlement has the role of a 'fluid object' which achieves relations of interdependence with other 'objects' thus achieving fluid network stabilization. As Karrholm (2012) suggests, the 
interdependence of settlements must be produced through multiscalar production of new 'objects'.

Thirdly, settlements must be characterized by hybridity and polyvalence that enables the proliferation of such relations. Spatial resilience of a settlement depends on how resilient the network of settlements itself is. At the same time, resilience of the whole network also depends on settlements.

\subsection{Network of settlements in Vojvodina}

A town is inseparable from the phenomenon of network and exists only in the immanent horizontal correlation with another town. According to Deleuze and Guattari (1980) it represents a threshold of deterritorialization, because whatever the material involved, it must be deterritorialized enough to enter the network, to submit to the polarization, to follow the circuit of urban and road recoding. Global network connectivity is disrupted by political organization and territorial division into a state (then a province, etc.) which has a tendency to disconnect a broader network of towns. Unlike the town, which is characterized by relations of trans-consistency and circulation, as stated by Deleuze and Guattari: "The State indeed proceeds otherwise: it is a phenomenon of intra-consistency. It makes points resonate together, points that are not necessarily already town-poles but very diverse points of order, geographic, ethnic, linguistic, moral, economic, technological particularities. It makes the town resonate with the countryside. It operates by stratification; in other words, it forms a vertical, hierarchized aggregate that spans the horizontal lines in a dimension of depth."

As a reflection of the state administration system, the system of urban planning in Serbia and Vojvodina is also hierarchically structured, with strict observance of the principle of vertical subordination of laws, plans, territory and administration. Space scales identify with administrative boundaries and typological classifications of areas so as to share the planning responsibility for solving, as Karrholm states, "intraterritorial problems and various fields of interest, which can lead to optimization of isolated elements, areas or aspects, but it will be harder for them to cope with multiple relations of the urban landscape." Accordingly, regional spatial plan of the Autonomous Province of Vojvodina (hereinafter RPPAPV) gives the following characterization of the network of settlements in Vojvodina:

"The network of settlements in Vojvodina has a favourable structure with welldifferentiated hierarchical relationship. (Figure1) Six major settlements with status of a city are evenly distributed on its territory: Sombor, Sremska Mitrovica, Subotica, Novi Sad, Zrenjanin and Pančevo. The city with the highest rank is Novi Sad, which, according to ESPON $^{2}$ classification is classified as a Functional urban area (FUA) of international importance, while other cities present functional urban areas of national importance. Lower rank nodes, which have the role of local catchment areas, are classified as urban settlements. All urban areas are interconnected and within their functional areas have conditions for good physical communication with other settlements thanks to a developed road network and main roads." Planning and strategies for development are still very much treated as territorial issues set within the frames of a "hardedged container", (Healy 2005), not fully dealing with the fact that a lot of relations, problems and phenomena are more and more enacted on new and multiple scales (Karrholm 2008). 

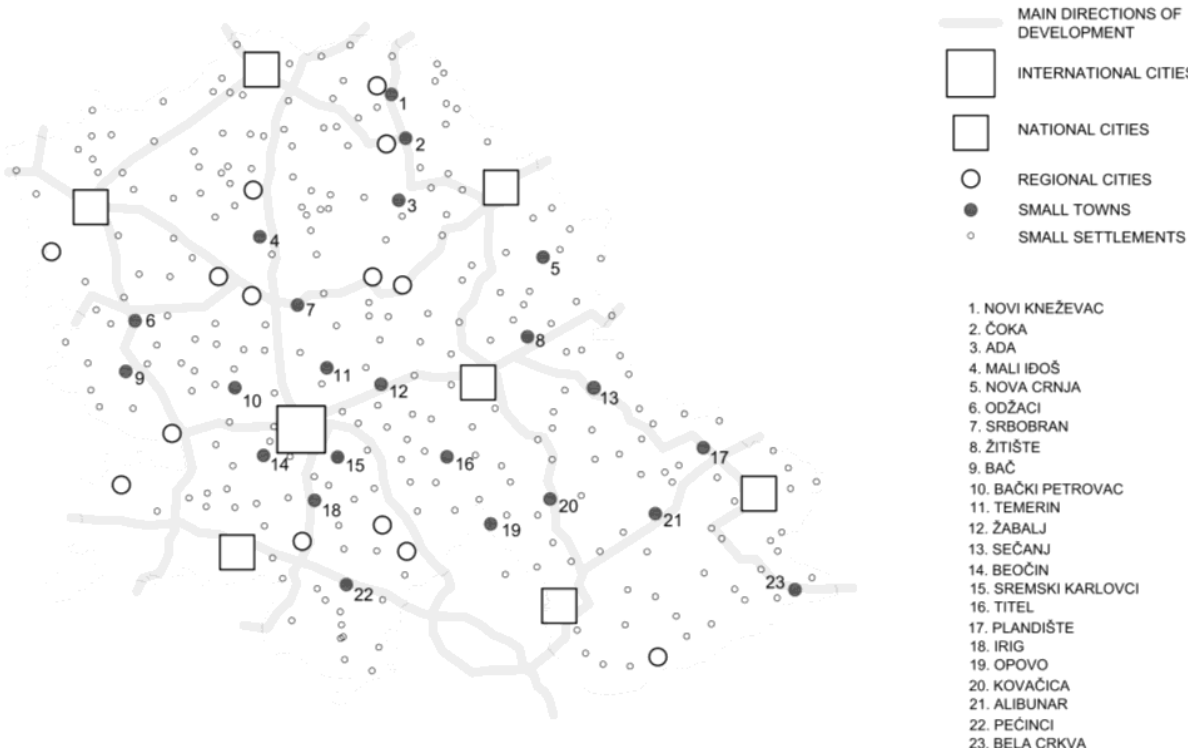

Fig. 1 Network of settlements in Vojvodina

It is clear that, if the intention is to view settlements in the light of spatial resilience, space needs to be understood using multiscalar approach, as a landscape of nested (urban) ecosystems in constant interaction. Processes of spatial and urban planning in Serbia are largely isolated and insufficiently interdisciplinary, and it is necessary to introduce a new understanding of space as continuous landscape.

Today's network of settlements in Vojvodina is relatively evenly developed owing to the general planning reconstruction of the entire system of settlements during the eighteenth century, laying down the basic guidelines for the spatial distribution of population, and thus the appearance of today's network of settlements. Clusters and networks of towns are formed at the level of larger spatial units between towns that cooperate or have complementary functions. They are the main support for development and the carrier of activation of local potentials that individual towns possess (Bajić Brković 2010).

The main characteristic of settlements in Vojvodina is inherited planned composition of geometric character. In Vojvodina there are a total of about 467 settlements, which, in the territory consisting of 45 municipalities, form a network with a relatively low population density - for every $100 \mathrm{~km}^{2}$ there is an average of 2.16 of settlements, which is far below the Republic average of 7.0 settlements per $100 \mathrm{~km}^{2}$.

\section{SMALL TOWNS AS URBAN-RURAL MEDIATORS}

In order to establish relations of interdependence of different settlements one needs to establish a mediator. We need a third object, an object that can hold two (or more) objects together, as well as helping us to get to know these two (or more) objects better. 
The proliferation of relational objects would also enhance the fluid stabilisation of settlements.

We identified small towns as key mediators in achieving relations of interdependence between different scales. Polyvalent urban-rural properties that characterize small towns are identified as relational objects that will establish interdependence through multiple scales with other types of settlements from the network.

The meanings of the terms "urban" and "rural" has always been based on emphasizing the difference between the two terms. This used to reflect more clearly marked differences between a town and a village, which are mirrored in the field of physical, social, cultural and economic dimensions of space. The differences could be accurately measured on a sociological level, using the criteria of population, population density and level of social diversity. However, complex transformation processes affecting settlements are of such character that they require reconsideration of the traditional binary division between town and village. Transformations are caused by the expansion of urban functions and an increasingly smaller share of agriculture in total economic activities in rural areas. This has also led to significant changes in the traditional understanding of the characteristics of rural (Kostreš 2012).

According to RPPAPV, settlements in Vojvodina are classified into three groups, based on the criteria of the size of settlements, population structure, level of development of certain town functions, position and importance within the network of settlements: (1) Towns macro-regional center and other regional centers; (2) Urban settlements - subregional and smaller centers; (3) Rural settlements (RPPAPV, 2011). As stated by said Kojić (1973), the majority of urban settlements in Vojvodina have the same urban-morphological characteristics as rural settlements as they have a similar urbanistic origin, and only did their development bring about differentiation. Therefore, in this case, both urban and rural are determined with the same planning character of settlements - measured and registered in the cadastre, with regulation, proper orthogonal network of streets and parcels, sewage and water infrastructure.

We will use information available in this classification regarding the categories of size and function and neglecting those categories that condition the establishment of any hierarchical relationship, such as position and importance. We will single out small towns which coincide in size and function with the second category of RPPAPV - Urban settlements - subregional and smaller centers; these include settlements whose population ranges from 2000 to 10000 residents, with the same morphogenetic characteristics, with a combination of agrarian function of rural character with the service or industrial function of urban character (RPPAPV 2011). In this group of settlements there is $44.14 \%$ of the population of Vojvodina. Also, these settlements include the maximum combining of urban functions with rural, i.e. agricultural, which are the basis of economic development of a province.

The combination of urban and rural character gives these settlements the polyvalent properties in terms of space, function and administration, and the potential of establishing a number of horizontal relations both in urban and rural areas. According to assumptions made by Bajec and Bajić (1992), settlements of 2000 - 5000 residents may constitute support within the network of settlements that can provide minimum basic services that cannot be provided in the villages. 


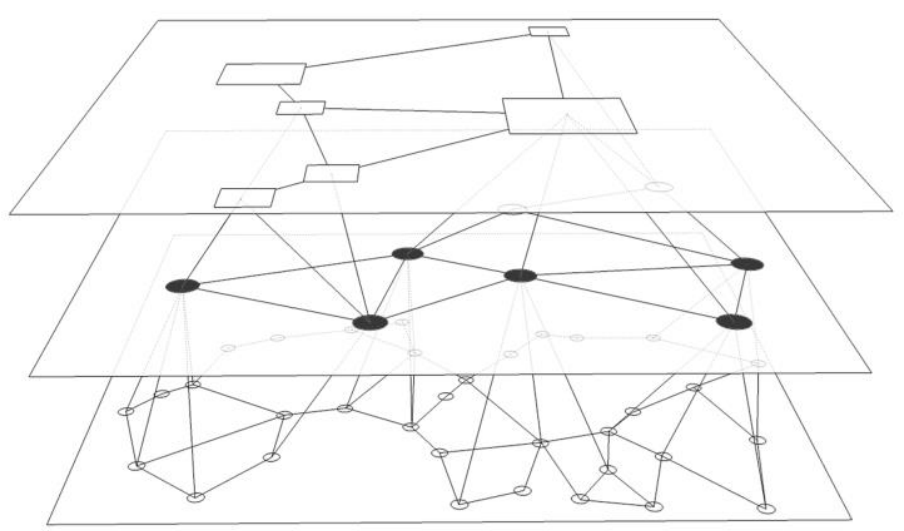

Fig. 2 Position of small towns in 'milieu'

Negative consequences of urbanization mainly affect rural areas and small towns that "empty" since the population migrates to larger urban centers. The reason for this should be sought in the overall possibilities offered by urban lifestyle in terms of employment, housing, education, health care services and other urban functions. As stated by Bajec and Bajić (1992) "(...) people have in their consciousness urbanization, which as a way of life, affected villages as well, and progressed far in some respects: hence the differences between towns and villages are rightfully expected to be disappearing." Negative tendencies of development of towns in Vojvodina are characterized by polarization, population growth and concentration in larger cities as well as suburbanization. On the other hand, depopulation in smaller towns threatens to jeopardize the balanced regional development that is considered to be an important development goal in the European context, where polycentric urban development is one of the goals of European policy makers. Therefore, attention should be directed towards declining rural areas and more careful consideration of the role of small and medium-sized towns (Spasić et al. 2007).

In relation to the urban-rural polarity, small towns are in the middle, disturbing such a binary division and allowing the establishment of a network consisting of varied settlements. Strengthening the network of small and medium-sized towns, the aim is to reduce this polarization between premium towns and periphery strengthening at the same time regional development. Small and medium-sized towns have a chance to re-evaluate rural areas and represent the 'golden mean' in urban and regional planning, combining the advantages of towns and rural areas (ibid.).

Position of small towns in 'milieu' is crucial for the environment (milieu), as they have the role of metacity and possess a maximum capacity of connecting with larger and smaller urban ecosystems. (Figure 2) They can be equally effectively connected with towns and villages, but settlements from the same category as well. However, realizing these potentials depends largely on how much they have developed their economies, and on the ways in which the links between them and larger towns are organized. If they serve only as a mediator in the exhaustion of rural areas and their resources, which are then invested in metropolitan areas, small towns represent a parasitic urban form. Since the mediator properties are crucial for the establishment of spatial resilience, 
development of small towns needs to be planned in accordance with features of "a resilient world", as precisely defined by Walker and Salt (2006):

1. Diversity: Promoting diversity in all its dimensions, from biological to economic, and encouraging multiple components and resource uses to balance and complement homogenizing trends.

2. Ecological variability: Seeking to understand and work with the boundaries of the inherent variability of ecological and socio-ecological systems; attempting to tame such variability is often a recipe for disaster.

3. Modularity: Maintaining modularity can help hedge against dangers of low resilience caused by over-connectedness in system structure and function.

4. Acknowledging slow variables: Managing for resilience means understanding the "slow" or controlling variables that underpin the condition of a system, especially in relation to thresholds. By recognizing the importance of these critical variables, we can better avoid shifts to undesirable stable states and possibly enhance the capacity of a desirable regime to deal with disturbances.

5. Tight feedbacks: Tightening or maintaining the strength of feedback loops allows us to better detect thresholds. The weakening of feedback loops can result in an asymmetry between our actions and the consequences stemming from them. Salient examples of such dynamics include pollution and overconsumption.

6. Social capital: Promoting trust, social networks, and leadership to enhance the adaptive capacity for better dealing with the effects of disturbance.

7. Innovation: Embracing change through learning, experimentation, and promoting locally developed rules. Instead of narrowing our range of activities and opportunities, we should be seeking to explore and cultivate new ones.

8. Overlap in governance: Developing institutional arrangements that manage for cross-scale influences. Developing "redundancy" and overlap in governance frameworks enhances response diversity and flexibility.

9. Ecosystem services: Recognizing and accounting for ecosystem services when managing and designing for resilience. The benefits society derives from nature are regularly underpriced and ignored. Such services are often lost as social-ecological systems shift into different, less desirable regimes.

In spatial and ecological terms, small towns have great potential regarding the development of green infrastructure, as strategically planned and maintained networks of green and water and other environmental elements that are vital to the ecological resilience of urban areas. The potential is based on the features of physical construction of these settlements, planned and built in the seventeenth century by the Austrian-Hungarian military planners and engineers, and modeled after the patterns of ideal garden cities of the time. These elements of urban matrix, which are integrally planned with agricultural systems, irrigation channels and roads in the function of agricultural production, are compatible with today's needs for adaptation of settlements to all kinds of social or environmental changes and allow a connected and permeable network of green infrastructure. 


\section{CONCLUDING REMARKS}

In this paper we reviewed the sustainable development of small towns in Vojvodina using the latest knowledge from the theory of resilient systems. We described achieving sustainability as a constant process of adaptation and response to the new conditions and sudden impacts. In order to provide an adequate answer, we established an interdisciplinary research framework, which integrated urban and spatial planning with a discourse of urban ecology and philosophy.

We assumed that resilience of one urban ecosystem, for example a small town in Vojvodina, needs to be regarded in a wider spatial context, without clearly drawn boundaries, with established relations of interdependence with other wider social-ecological systems.

To form an integral frame for the qualification of spatial resilience of urban ecosystems, i.e. small towns in Vojvodina, we used concepts of three disciplinary discourses: ecological, philosophical discourse and architectural-urban discourse as well as concepts of panarchy, metacity, polyvalence and flexibility.

Because of the inherent relationship between a town and its 'milieu', we expanded the context of ecological resilience of a town as an urban ecosystem. For this purpose we used the concept of spatial resilience, as dynamic capacity of the system to cope with disturbances and environmental thresholds on spatial scales larger than an individual ecosystem.

Acknowledgements: This paper was realized as a part of the research project "Studying climate change influence on the environment: impacts, adaptation and mitigation" (Grant No. TR43007) financed by Ministry of Education and Science of the Republic of Serbia within the framework of integrated and interdisciplinary research for the period 2011-2014.

\section{REFERENCES}

1. Allaby, Michael. Ecology: Plants, Animals, and the Environment. London: Facts on File, Inc., 2009.

2. Alberti, Marina. "The Effects of Urban Patterns on Ecosystem Function." International Regional Science Review, no. 28 (2005), 168-192.

3. Alberti, Marina. "Urban Patterns and Environmental Performance: What Do We Know?" Journal of Planning Education and Research, no. 19 (1999), 151-163.

4. Bajec Lazarević, Nada, and Milica Bajić. "Prostorna dimenzija razvoja." U Bajec Lazarević, N. (urednik) Istraživanje prostora. 51-77. Urbanologija. Beograd: Arhitektonski fakultet, 1992.

5. Bajić Brković, Milica. "Ka održivom razvoju gradova u Srbiji“, in Bajić Brković, M. (ed.) Kreativne strategije održivog razvoja u Srbiji, 13-48. Beograd: Arhitektonski fakultet, 2010.

6. Ballantyne, Andrew. Deleuze and Guattari for Architects. London and New York: Routledge, 2007.

7. Bogdanov, Natalija. Mala ruralna domaćinstva u Srbiji i ruralna nepoljoprivredna ekonomija. Beograd: UNDP , 2007

8. Deleuze, Gilles. and Felix Guattari. Capitalisme et schizophrénie 2: Mille plateaux; translated by Brian Massumi (1987) Capitalism and Schizophrenia 2: A Thousand Plateaus, Minneapolis, MN: Minnesota University Press, 1980.

9. Folke, Carl. "Resilience: The emergence of a perspective for social-ecological systems analyses." Global Environmental Change, no. 16 (2006), 253-267.

10. Harman, Graham. Prince of networks. Melbourne: Re-press, 2009.

11. Healy, Patsy. "Network Complexity and Imaginative Power" in The Network Society, eds. L. Albrechts

12. \& S. Mandelbaum. London: Routledge, 2005. 
13. Hertzberger, Herman. Lessons for students in architecture. Rotterdam: 010 Publishers, 2001.

14. Holling, Crawford Stanley. "Resilience and stability of ecological systems." Annual Review of Ecology and Systematics, no. 4 (1973), 1-23.

15. Kärrholm, Mattias. "The scaling of sustainable urban form - Some scale-related problems in the context of a Swedish urban landscape.” European Planning Studies, no. 19 (2011), 97-112.

16. Kärrholm, Mattias, Katarina Nylund, Paulina Prieto de la Fuente. "Spatial resilience and urban planning: Addressing the interdependence of urban retail areas." Cities, no. 36 (2014) 121-130.

17. Kojić, Branislav. Seoska arhitektura i rurizam, Beograd: Građevinska knjiga, 1973.

18. Kostreš, Milica. „Urbano-ruralne veze i odnosi između naselja.“ Doktorska disertacija. Univerzitet u Novom Sadu: Fakultet tehničkih nauka, 2012.

19. Law, John. "Objects and spaces." Theory, Culture and Society, no. 19 (5/6) (2002), 91-105.

20. Nyström, M., and Folke, C. Spatial resilience of coral reefs. Ecosystems, no. 4 (2001), 406-417.

21. Pickett, Steward. T. A., Cadenasso, M. L., and Grove, J. M. "Resilient cities: meaning, models, and metaphor for integrating the ecological, socioeconomic, and planning realms." Landscape and Urban Planning, no. 69 (2004), 369-384.

22. Regionalni prostorni plan autonomne pokrajine Vojvodine, Pokrajinski zavod za urbanizam i prostorno planiranje, 2011.

23. Spasić, Nenad, Jasna Petrić, Marko Filipović. Small and Medium Towns of Central Serbia. Belgrade: Institute of Architecture and Urban \& Spatial Planning of Serbia, 2007.

24. Walker, Brian Harrison, and Salt, David. Resilience thinking: sustaining ecosystems and people in a changing world. Washington, DC: Island Press, 2006.

\section{MALI GRADOVI KAO MEDIJATORI PROSTORNE REZILIJENTNOSTI: STUDIJA SLUČAJA MREŽE NASELJA U VOJVODINI}

Razvoj naselja u Vojvodini je opterećen brojnim problemima, kako ekološke, tako i socijalne prirode, što ozbiljno ugrožava njihov put ka održivosti. Efekti klimatskih promena su identifikovani u najvećoj meri u vidu poplava, izlivanja reka i dugotrajnih suša koje utiču na poljoprivredu kao dominantnu aktivnost u regionu. S druge strane, naselja u Vojvodini, posebno mali gradovi i seoska naselja, pate od hronične depopulacije i efekta 'pražnjenja'. To naravno svoje posledice prenosi na veće gradove i celokupnu regionalnu mrežu naselja.

U ovom članku ćemo se fokusirati na poseban tip naselja u Vojvodini- male gradove, specifične zbog svog urbano-ruralnog karaktera i njihovog značaja u okviru gore navedenog problema. Koje su mogućnosti da ovaj tip naselja unapredi svoju ekološku rezilijentnost, svojstvo koje je condicio sine qua non održivosti?

Naša pretpostavka je da upravo mali gradovi, zbog svog hibridnog urbano-ruralnog karaktera, poseduju dovoljnu fleksibilnost i polivalentnost da preuzmu ulogu 'fludinog objekta' tj. medijatora koji omogućava proliferaciju relacionih objekata između urbanih i ruralnih naselja, $i$ koji će omogućiti prostornu rezilijentnost celokupne mreže naselja. Koristićemo koncept prostorne rezilijentnosti kako bi pitanje ekološke rezilijentnosti jednog tipa naselja proširili na celokupnu mrežu gradova.

Ključne reči: prostorna rezilijentnost, socio-ekološki sistemi, mali gradovi, mreža gradova u Vojvodini 